\title{
Evaluation of Genetic Diversity among Different Melia composita CPTs using Random Amplified Polymorphic DNA (RAPD) Markers
}

\author{
Vishal Johar*, R. S. Dhillon and Amit Singhdoha
}

Dept. of Forestry, CCS Haryana Agricultural University, Hisar, Haryana (125 004), India

\section{Corresponding Author}

Vishal Johar

e-mail: vishaljohar89@gmail.com

\author{
Article History \\ Article ID: 3C0105 \\ Received in 06 ${ }^{\text {th }}$ September, 2017 \\ Received in revised form $22^{\text {nd }}$ December, 2017 \\ Accepted in final form $24^{\text {th }}$ January, 2018
}

\begin{abstract}
The present study was conducted to evaluate the genetic diversity among different candidate plus trees (CPTs) of Melia composita for providing a wider base for the further improvement of this versatile short rotation tree species. RAPD molecular markers were used to evaluate the genetic diversity in populations of Melia composita Willd. (Burma dek) from different agroclimatic regions. Out of the 38 decamer primers used, 13 yielded polymorphic banding patterns. In total, 105 different bands were reproducibly obtained, out of which 69 (65.7\%) were polymorphic. The polymorphisms were scored and used in band-sharing analysis to identify genetic relationships. Cluster analysis based on Jaccard's similarity coefficient using UPGMA grouped all the 24 populations into two major groups. Similarity indices ranged from 0.80 to 0.91 , indicating that Burma dek germplasm within India constitutes considerably narrow genetic base. The present study reveals that PCR based fingerprinting technique, RAPD; is informative for estimating the extent of genetic diversity as well as to determine the pattern of genetic relationships between different candidate plus trees (CPTs) of Melia composita with polymorphism levels sufficient to establish informative fingerprints with relatively fewer primer sets. Hence the study provides a basis for tree breeders to make informed choices on selection of parental material based on genetic diversity to help overcome some of the problems usually associated with a tree crop improvement program.
\end{abstract}

Keywords: Melia composita, RAPD, Genetic diversity, candidate plus trees

\section{Introduction}

Melia composita (Willd.), commonly known as Burma dek, white cedar, Malabar neem, drek (Swaminathan et al., 2012), belongs to family Meliaceae. It is a deciduous tree, native to Indian sub-continent but now has spread in many Asian countries and also in different regions of the globe (Murugesan et al., 2013). Melia composita being a fast growing short rotation tree species and can be exploited for bio-energy applications especially for biomass gasification to generate producer gas and use in Lime Kiln to replace fuel oil and also for other wood product applications (Chinnaraj et al., 2011). Melia compositais valued for its high-quality termite and fungus resistant timber (Swaminathan et al., 2012). The multipurpose industrial wood is suitable for the manufacturing of packing cases, cigar boxes, ceiling planks, building and construction material, agricultural implements, pencils, match boxes, splints, musical instruments, tea boxes, ply board and fuel wood (Calorific value, 5.043 - 5,176 cal.) and also due its decorative appearances, which makes it suitable for furniture making (Mandang and Artistien, 2003). Every part of this versatile tree species is being used as traditional herbal medicines, such as anthelmintics, treatment of leprosy, eczema, asthma, malaria, fevers and venereal disease (Govindachari, 1992), as well as cholelithiasis, acariasis and pain (Kokwaro, 1976). Fruitsused in folk medicine as an antihelmintic, astringent and in the treatment of colic (Kiritkar and Basu, 1999). It is well known as a rich and valuable source of bioactive limonoids (Awang et al., 2007) which are highly oxygenated and modified terpenoids having insecticidal, antibacterial, antifungal, anti-malarial, anticancer, antiviral and pharmaceutical properties (Endo et al., 2002; Koul et al., 2004).

Inspite of it's such a high value; required efforts have not been made for its genetic improvement. Genetic diversity and natural distribution pattern are very important for the introduction and conservation. The range of genetic variability is controlled by reproductive systems which in turn controls the adaptive change (Simmonds, 1962). The relative genetic diversity among individuals or populations can be determined using morphological and molecular markers. Phenotypic characters have a limited importance since they are considerably influenced by environmental factors and developmental stages of the plant and also due to the fact that 
in some species adequate levels of phenotypic polymorphism are not available (Tatineni et al., 1996). On the contrary, molecular markers, based on DNA sequence polymorphism, are independent of environmental conditions and shows higher levels of polymorphism. Several methods such as isozymes or restriction fragment length polymorphisms (RFLPs) have been used in the analysis of genetic relationship in different species (Soltis and Soltis, 1990; Wang et al., 1994). Genetic diversity and natural distribution pattern are very important for the introduction and conservation. Random amplified polymorphic DNAs (RAPDs) have been widely employed for their simplicity and capacity to detect genetic variation in natural populations (Karp et al., 1998). The lack of reproducibility is considered to be its limitation, but studies show that the results of RAPD can be reproduced in a stable polymerase chain reaction (PCR) system (Wang et al., 2003). The objective of the present investigation was to evaluate genetic diversity using RAPD markers in Melia composita.

\section{Materials and Methods}

\subsection{Plant material}

Candidate plus trees (CPTs) were selected based on an intensive survey of different agroclimatic regions of Haryana, Punjab, Uttrakhand and Himachal Pradesh (Table 1). The selection was made on phenotypic assessment of desirable characters of economic interest such as stem straightness, self-pruning ability; clear bole height, low branching habit, disease resistance, etc. The juvenile (young) leaves of nursery raised progenies of different candidate plus trees formed the basic material for present study.

\subsection{DNA extraction}

DNA was isolated following the protocol of Murray and Thompson (1980), modified by Saghai-Maroof et al. (1984) and $\mathrm{Xu}$ et al. (1994). Fresh young leaves from individual nursery grown progenies of plus trees were collected in icebox. Three to four grams of tissue was ground to a very fine powder in liquid nitrogen using mortar and pestle. The powder was transferred to a $50 \mathrm{ml}$ polypropylene centrifuge tube containing $20 \mathrm{ml}$ of pre-warmed $\left(60^{\circ} \mathrm{C}\right)$ DNA extraction buffer (3.5 g CTAB; $5 \mathrm{M} \mathrm{NaCl}$; 0.5 M EDTA, pH 8.0; 1 M Tris, pH $8.0 ; 2 \mathrm{ml} \beta$-mercaptoethanol). The suspension was incubated in water bath at $65{ }^{\circ} \mathrm{C}$ for 2 hours with intermittent swirling. After incubation, the mixture was emulsified with an equal volume of chloroform: iso-amyl alcohol mixture (24:1) for 10-15 minutes by swirling. The content was centrifuged at $10,000 \mathrm{rpm}$ for 20 minutes at room temperature. The upper aqueous phase (supernatant) was transferred in a presterilized centrifuged tube and again extracted with an equal volume of chloroform: iso-amyl alcohol (24:1). Thus, following centrifugation, the aqueous phase was collected and mixed with equal volume of chilled isopropanol and was left for over-night at $-20{ }^{\circ} \mathrm{C}$ temperature. The precipitated DNA was spooled out with help of micro-pipette and was centrifuged at $13,000 \mathrm{rpm}$ for 15 minutes at $4^{\circ} \mathrm{C}$ temperature to form DNA
Table 1: Geological location of selected Plus trees of Melia composite

\begin{tabular}{|c|c|c|c|}
\hline $\begin{array}{l}\text { SI. } \\
\text { No. }\end{array}$ & $\begin{array}{c}\text { Asses- } \\
\text { sion } \\
\text { code }\end{array}$ & $\begin{array}{l}\text { Geographi- } \\
\text { cal source }\end{array}$ & Latitudes and Longitudes \\
\hline 1. & MCS1 & $\begin{array}{l}\text { Himachal } \\
\text { Pradesh }\end{array}$ & $30^{\circ} 50^{\prime} \mathrm{N}$ and $77^{\circ} 11^{\prime} 30^{\prime \prime} \mathrm{E}$ \\
\hline 2. & MCPN1 & Uttrakhand & $29^{\circ} \mathrm{N}$ and $79.29^{\circ} \mathrm{E}$ \\
\hline 3. & MCBI1 & Haryana & $29^{\circ} 33^{\prime} 0^{\prime \prime} \mathrm{N}$ and $75^{\circ} 56^{\prime} 0^{\prime \prime} \mathrm{E}$ \\
\hline 4. & MCBI2 & -do- & $29^{\circ} 33^{\prime} 0^{\prime \prime} \mathrm{N}$ and $75^{\circ} 56^{\prime} 0^{\prime \prime} \mathrm{E}$ \\
\hline 5. & MCBI3 & - do- & $29^{\circ} 33^{\prime} 0^{\prime \prime} \mathrm{N}$ and $75^{\circ} 56^{\prime} 0^{\prime \prime} \mathrm{E}$ \\
\hline 6. & MCBI4 & -do- & $29^{\circ} 33^{\prime} 0^{\prime \prime} \mathrm{N}$ and $75^{\circ} 56^{\prime} 0^{\prime \prime} \mathrm{E}$ \\
\hline 7. & MCBI5 & -do- & $29^{\circ} 33^{\prime} 0^{\prime \prime} \mathrm{N}$ and $75^{\circ} 56^{\prime} 0^{\prime \prime} \mathrm{E}$ \\
\hline 8. & MCP1 & Punjab & $30^{\circ} 65^{\prime} \mathrm{N}$, and $75^{\circ} 69^{\prime} \mathrm{E}$ \\
\hline 9. & MCP3 & -do- & $24^{\circ} 20^{\prime} \mathrm{N}$ and $72^{\circ} 44 \mathrm{E}$ \\
\hline 10. & MCP5 & -do- & $24^{\circ} 20^{\prime} \mathrm{N}$ and $72^{\circ} 44 \mathrm{E}$ \\
\hline 11. & MCP6 & -do- & $21^{\circ} 39^{\prime} \mathrm{N}$ and $73^{\circ} 43 \mathrm{E}$ \\
\hline 12. & MCP7 & -do- & $21^{\circ} 39^{\prime} \mathrm{N}$ and $73^{\circ} 43 \mathrm{E}$ \\
\hline 13. & MCP10 & -do- & $30^{\circ} 42^{\prime} \mathrm{N}$ and $75^{\circ} 18^{\prime} \mathrm{E}$ \\
\hline 14. & MCP11 & -do- & $30^{\circ} 42^{\prime} \mathrm{N}$ and $75^{\circ} 18^{\prime} \mathrm{E}$ \\
\hline 15. & MCP12 & - do- & $30^{\circ} 42^{\prime} \mathrm{N}$ and $75^{\circ} 18^{\prime} \mathrm{E}$ \\
\hline 16. & MCP14 & -do- & $29^{\circ} 43^{\prime} \mathrm{N}$ and $76^{\circ} 13^{\prime} \mathrm{E}$ \\
\hline 17. & MCP15 & -do- & $29^{\circ} 43^{\prime} \mathrm{N}$ and $76^{\circ} 13^{\prime} \mathrm{E}$ \\
\hline 18. & MCPAU1 & Punjab & $30^{\circ} 90^{\prime} \mathrm{N}$ and $75^{\circ} 81^{\prime} \mathrm{E}$ \\
\hline 19. & MCPAU2 & -do- & $30^{\circ} 90^{\prime} \mathrm{N}$ and $75^{\circ} 81^{\prime} \mathrm{E}$ \\
\hline 20. & MCPAU3 & -do- & $30^{\circ} 90^{\prime} \mathrm{N}$ and $75^{\circ} 81^{\prime} \mathrm{E}$ \\
\hline 21. & MCPAU5 & -do- & $30^{\circ} 90^{\prime} \mathrm{N}$ and $75^{\circ} 81^{\prime} \mathrm{E}$ \\
\hline 22. & MCK1 & Haryana & $29.96^{\circ} \mathrm{N}, 76.83^{\circ} \mathrm{E}$ \\
\hline 23. & MCK2 & -do- & $29.96^{\circ} \mathrm{N}, 76.83^{\circ} \mathrm{E}$ \\
\hline 24. & MCB1 & Punjab & $30^{\circ} 10^{\prime} \mathrm{N}$ and $75^{\circ} 09^{\prime} \mathrm{E}$ \\
\hline
\end{tabular}

pellets. After pellet formation, DNA was washed with help of $70 \%$ alcohol for 2 times. The washed DNA was dried at room temperature for 4-6 hrs and was subsequently dissolved in $100 \mu$ of TE (Tris $10 \mathrm{mM}$, EDTA $1 \mathrm{mM}$ ) buffer.

DNA Quantification

Quantification of DNA was accomplished by analyzing the purified DNA on $1 \%$ agarose gel alongside diluter uncut lambda DNA as standard. DNA was diluted in TE to a concentration ofapproximately $12.5 \mathrm{ng} / \mu \mathrm{l}$ for use in PCR analysis.

\subsection{DNA amplification}

A total of 38 RAPD primers from Life Technologies Corporation (Table 2) were used for PCR amplification.PCR amplification were performed using 96 well thermal cycler (Quanta biotech, Model S20143) using $20 \mu$ I PCR reaction mixture containing 1 $X$ PCR buffer (50 mMKCl, 10 mMTris-Cl, $1.5 \mathrm{mM} \mathrm{MgCl}_{2}$ ), 200 


\begin{tabular}{|c|c|c|c|c|c|}
\hline SI. No. & Primer & Sequence $\left(5^{\prime}-3^{\prime}\right)$ & $\mathrm{G}+\mathrm{C}$ content $(\%)$ & Melting temperature (Tm) & Annealing temperature $(\mathrm{Ta})$ \\
\hline 1. & MA 16 & TGAGCCTCAC & 55 & 33.7 & 37.3 \\
\hline 2. & MA 18 & GGTGCGGGAA & 55 & 40.4 & 40.8 \\
\hline 3. & MA 19 & CCAGATGCAC & 70 & 32.6 & 35.7 \\
\hline 4. & MA 20 & GTGACATGCC & 60 & 33.2 & 33.4 \\
\hline 5. & MA 21 & TCAGGGAGGT & 65 & 33.9 & 34.9 \\
\hline 6. & MA 24 & CACCAGGTGA & 55 & 33.4 & 38.3 \\
\hline 7. & MA 25 & GAGTCTCAGG & 75 & 29.5 & 31.9 \\
\hline 8. & MA 26 & GGTGACTGTG & 55 & 31.8 & 35.7 \\
\hline 9. & MA 27 & GGCACGTAAG & 60 & 32.9 & 37.7 \\
\hline 10. & MA 28 & AAGTCCGCTC & 60 & 34.6 & 34.1 \\
\hline 11. & MA 29 & CCCAGTCACT & 65 & 32.8 & 37.3 \\
\hline 12. & MA 30 & CCACGGGAAG & 55 & 36.6 & 40.0 \\
\hline 13. & MA 31 & CAGCACTGAC & 70 & 32.7 & 41.5 \\
\hline 14. & MA 32 & TCAGAGCGCC & 65 & 40.1 & 35.4 \\
\hline 15. & MA 33 & GACAGGAGGT & 65 & 32.2 & 30.3 \\
\hline 16. & MA 34 & GTCCACTGTG & 60 & 31.8 & 32.2 \\
\hline 17. & MA 35 & GAGGATCCCT & 70 & 30.9 & 32.2 \\
\hline 18. & MA 36 & GTCGCCGTCA & 70 & 40.8 & 41.4 \\
\hline 19. & MA 37 & TCTGGTGAGG & 60 & 32.2 & 37.9 \\
\hline 20. & MA 38 & CACCGTATCC & 60 & 38.0 & 33.5 \\
\hline 21. & MA 39 & CATCCGTGCT & 65 & 35.8 & 40.1 \\
\hline 22. & MA 40 & AGGGCGTAAG & 55 & 33.9 & 38.3 \\
\hline 23. & MA 41 & CCAAGCTTCC & 67 & 32.3 & 34.1 \\
\hline 24. & MA 42 & TGCCCGTCGT & 55 & 43.2 & 45.1 \\
\hline 25. & MA 43 & GGAAGCTTGG & 65 & 32.3 & 33.3 \\
\hline 26. & MA 44 & GGGACGATGG & 60 & 36.2 & 31.6 \\
\hline 27. & MA 45 & AGCAGGTGGA & 56 & 36.0 & 37.9 \\
\hline 28. & MA 46 & TGTCATCCCC & 55 & 32.8 & 34.3 \\
\hline 29. & LD 3230 & AATCGGGCTG & 63 & 32.0 & 33.5 \\
\hline 30. & LD 3231 & CAATCGCCGT & 58 & 32.0 & 35.1 \\
\hline 31. & LD 3233 & GACCGCTTGT & 75 & 32.0 & 31.1 \\
\hline 32. & LD 3235 & TCGCCGCAAA & 70 & 32.0 & 30.7 \\
\hline 33. & LD 3236 & AGCGTCACTC & 60 & 32.0 & 36.6 \\
\hline 34. & LD 3247 & AAAGCTGCGG & 65 & 32.0 & 36.5 \\
\hline 35. & LD 3248 & GACGGATCAG & 70 & 32.0 & 30.5 \\
\hline 36. & LD 3252 & GTTGCCACCC & 62 & 34.0 & 38.3 \\
\hline 37. & LD 3256 & GTCCACACGG & 65 & 34.0 & 37.2 \\
\hline 38. & LD 3258 & CTGCTGGGAC & 60 & 34.0 & 36.1 \\
\hline
\end{tabular}

$\mu \mathrm{M}$ each of dNTPs, $20 \mathrm{ng}$ of primer, 0.45 unit of Taq DNA DNA template. The first cycle consisted of denaturation of polymerase (New England Biolabs, Pvt., Ltd.) and $50 \mathrm{ng}$ of template DNA at $94^{\circ} \mathrm{C}$ for 4 min, primer annealing $\left(37^{\circ} \mathrm{C}\right)$ for 
$1 \mathrm{~min}$ and primer extension $\left(72^{\circ} \mathrm{C}\right)$ for $1 \mathrm{~min}$. in the next 47 cycles, the period of denaturation was reduced to 1 min while the primer annealing and the primer extension time remained as in the first cycle. The last cycle consisted of only primer extension $\left(72^{\circ} \mathrm{C}\right)$ for $10 \mathrm{~min}$. Amplified DNA fragments were separated on a $1.5 \%$ agarose gel in $1 X$ Tris-Borate EDTA buffer. The size (bp) of most intensely amplified band for each RAPD marker was determined based on its migration relative to molecular weight of DNA ladder (Gene Ruler ${ }^{\mathrm{TM}} 1 \mathrm{~Kb}$ and $10 \mathrm{bp}$ DNA Ladder). The DNA bands were visualized by staining the gels with nucleic acid stain and photographed under UV light using gel documentation system (Alpha Innotech Corporation, California, USA). The experiments were repeated at least twice to confirm the results.

\subsection{Band scoring and data analysis}

The frequency of RAPD polymorphism between 24 genotypes of Burma dek was calculated based on the presence of band ' 1 ' or absence of band ' 0 '. The genetic association among genotypes was evaluated by calculating the Jaccard's similarity co-efficient for pair-wise comparison based on the proportions of shared bands produced by primers. Similarity matrix was generated using 'Simqual' sub-program of software NTSYS-PC (Rohlf, 1990). Jaccard similarity coefficients were used for cluster analysis of genotypes using 'SAHN' sub-program and dendrogram based on UPGMA. Principle component analysis
(NTSYS-PC) was performed to generate a two and three dimensional representation of genetic relationship among 24 genotypes of Melia composita.

\section{Results and Discussion}

Out of 38 decamer primers screened, only 13 were found to produce intensely stained and reproducible polymorphic bands among 24 genotypes of Melia composita while the rest of the primers resulted in either no amplification or smeared profiles. A total 105 amplified bands were obtained, out of which 36 were monomorphic and 69 were polymorphic (Table $3)$. Average polymorphism across all the 24 genotypes of M.composita was found to be $65.71 \%$. The size of amplified products ranged from 200-4937 bp in size. Such a high level of polymorphism might be due to the use of primers with high GC content. The GC content is an important criterion for the selection of primers because it is associated with Tm (annealing temperature) and related to the reproducibility of results (Dhillon et al., 2012). The higher GC contents produced higher frequencies of RAPD because of increase in total frequencies of amplified fragments. The number of bands (fragments) per primer ranged from 4 (MA 33) to 11 (MA 39, MA 45), the average number of bands per primer being 8 .

The pair-wise comparison of the RAPD profiles based on both shared and unique amplification products were made

\begin{tabular}{|c|c|c|c|c|c|c|}
\hline Primer code & $\begin{array}{l}\text { Nucleotide se- } \\
\text { quence }\left(5^{\prime}-3^{\prime}\right)\end{array}$ & $\begin{array}{l}\text { Total No. of am- } \\
\text { plified fragments }\end{array}$ & $\begin{array}{l}\text { No. of monomor- } \\
\text { phic fragments }\end{array}$ & $\begin{array}{l}\text { No. of polymor- } \\
\text { phic fragments }\end{array}$ & $\begin{array}{c}\text { Fragment size } \\
\text { range }(\mathrm{bp})\end{array}$ & PIC values \\
\hline MA 16 & TGAGCCTCAC & 7 & 3 & 4 & $425-3247$ & 0.67 \\
\hline MA 28 & AAGTCCGCTC & 8 & 5 & 3 & $252-4509$ & 0.87 \\
\hline MA 29 & CCCAGTCACT & 6 & 2 & 4 & $418-4454$ & 0.64 \\
\hline MA 30 & CCACGGGAAG & 9 & 4 & 5 & $255-4937$ & 0.55 \\
\hline MA 31 & CAGCACTGAC & 7 & 4 & 3 & $200-3856$ & 0.60 \\
\hline MA 32 & TCAGAGCGCC & 10 & 4 & 6 & $450-4869$ & 0.41 \\
\hline MA 33 & GACAGGAGGT & 4 & 1 & 3 & $327-4416$ & 0.63 \\
\hline MA 36 & GTCGCCGTCA & 8 & 3 & 5 & $395-3982$ & 0.35 \\
\hline MA 39 & CATCCGTGCT & 11 & 1 & 10 & $350-3407$ & 0.57 \\
\hline MA 41 & CCAAGCTTCC & 8 & 3 & 5 & $404-3916$ & 0.82 \\
\hline MA 44 & GGGACGATGG & 8 & 3 & 5 & $350-3676$ & 0.62 \\
\hline MA 45 & AGCAGGTGGA & 11 & 3 & 8 & $433-4201$ & 0.52 \\
\hline LD 3256 & GTCCACACGG & 8 & 0 & 8 & $307-2992$ & 0.75 \\
\hline Total & & 105 & 36 & 69 & & \\
\hline
\end{tabular}

to generate a similarity matrix. The mean genetic similarity as obtained from similarity matrix (Table 4) varied from 80.3 to of $91.2 \%$ within 24 genotypes. The maximum similarity value (0.91) was observed between MCPN1 and MCPAU3 genotypes selected from Uttrakhand and Punjab, respectively indicating these genotypes to be most closely related genotypes. The climatic conditions of these places are drastically different but these conditions don't seem to have played a role in evolving genetic diversity in Melia composita. However, the lower value of the similarity coefficient was observed between MCBI4 and MCP10 (80.3) genotypes selected from Haryana and Punjab, respectively. Such a narrow range in similarity co-efficient 


\begin{tabular}{|c|c|c|c|c|c|c|c|c|c|c|c|c|c|}
\hline & MCP3 & MCP & P5 MC & P6 MCP7 & 7 MCP10 & MCP11 & MCP12 & MCP14 & $4 \mathrm{MCP} 15$ & 15 MCS & \multicolumn{2}{|c|}{ MCPAU1 } & MCPAU2 \\
\hline MCP3 & 1 & & & & & & & & & & & & \\
\hline MCP5 & 0.87 & 1 & & & & & & & & & & & \\
\hline MCP6 & 0.86 & 0.87 & 1 & & & & & & & & & & \\
\hline MCP7 & 0.84 & 0.86 & 0.85 & 1 & & & & & & & & & \\
\hline MCP10 & 0.81 & 0.85 & 0.82 & 0.85 & 1 & & & & & & & & \\
\hline MCP11 & 0.82 & 0.85 & 0.83 & 0.84 & 0.84 & 1 & & & & & & & \\
\hline MCP12 & 0.84 & 0.87 & 0.8 & 0.87 & 0.84 & 0.86 & 1 & & & & & & \\
\hline MCP14 & 0.83 & 0.86 & 0.85 & 0.85 & 0.84 & 0.84 & 0.87 & 1 & & & & & \\
\hline MCP15 & 0.83 & 0.85 & 0.85 & 0.84 & 0.83 & 0.83 & 0.85 & 0.85 & 1 & & & & \\
\hline MCS1 & 0.83 & 0.85 & 0.8 & 0.84 & 0.84 & 0.84 & 0.86 & 0.84 & 0.86 & 1 & & & \\
\hline MCPAU1 & 0.86 & 0.88 & 0.86 & 0.86 & 0.84 & 0.85 & 0.88 & 0.86 & 0.87 & 0.88 & 1 & & \\
\hline MCPAU2 & 0.87 & 0.87 & 0.86 & 0.85 & 0.84 & 0.84 & 0.85 & 0.85 & 0.85 & 0.87 & 0.91 & 1 & 1 \\
\hline MCPAU5 & 0.86 & 0.88 & 0.86 & 0.86 & 0.85 & 0.85 & 0.86 & 0.86 & 0.86 & 0.88 & 0.90 & & 0.89 \\
\hline MCB1 & 0.84 & 0.85 & 0.8 & 0.85 & 0.83 & 0.83 & 0.84 & 0.84 & 0.84 & 0.85 & 0.87 & & 0.86 \\
\hline MCPN1 & 0.85 & 0.87 & 0.86 & 0.85 & 0.84 & 0.85 & 0.86 & 0.86 & 0.85 & 0.86 & 0.89 & & 0.88 \\
\hline MCPAU3 & 0.85 & 0.86 & 0.85 & 0.85 & 0.84 & 0.84 & 0.85 & 0.85 & 0.84 & 0.85 & 0.88 & & 0.87 \\
\hline MCBI1 & 0.85 & 0.87 & 0.85 & 0.85 & 0.83 & 0.84 & 0.85 & 0.85 & 0.85 & 0.86 & 0.88 & & 0.88 \\
\hline MCBI2 & 0.82 & 0.83 & 0.8 & 0.83 & 0.80 & 0.81 & 0.82 & 0.81 & 0.81 & 0.83 & 0.85 & & 0.84 \\
\hline MCBI3 & 0.83 & 0.86 & 0.8 & 0.84 & 0.82 & 0.83 & 0.85 & 0.84 & 0.84 & 0.85 & 0.87 & & 0.86 \\
\hline MCBI4 & 0.81 & 0.84 & 0.82 & 0.82 & 0.8 & 0.81 & 0.83 & 0.82 & 0.81 & 0.83 & 0.85 & & 0.84 \\
\hline MCBI5 & 0.82 & 0.84 & 0.83 & 0.83 & 0.81 & 0.82 & 0.84 & 0.83 & 0.83 & 0.84 & 0.86 & & 0.85 \\
\hline MCK1 & 0.85 & 0.87 & 0.86 & 0.86 & 0.84 & 0.85 & 0.87 & 0.86 & 0.86 & 0.88 & 0.89 & & 0.88 \\
\hline MCK2 & 0.83 & 0.85 & 0.83 & 0.83 & 0.81 & 0.82 & 0.84 & 0.83 & 0.83 & 0.84 & 0.87 & & 0.86 \\
\hline MCP1 & 0.84 & 0.86 & 0.85 & 0.84 & 0.82 & 0.83 & 0.84 & 0.85 & 0.84 & 0.85 & 0.87 & & 0.87 \\
\hline \multicolumn{14}{|c|}{ Table 4: Continue... } \\
\hline & \multicolumn{2}{|c|}{ MCPAU5 I } & MCB1 & MCPN1 & MCPAU3 & MCBI1 & MCBI2 & MCBI3 & MCBI4 N & MCBI5 & MCK1 & MCK2 & MCP1 \\
\hline MCPAU5 & 1 & & & & & & & & & & & & \\
\hline MCB1 & 0.88 & & 1 & & & & & & & & & & \\
\hline MCPN1 & 0.89 & & 0.89 & 1 & & & & & & & & & \\
\hline MCPAU3 & 0.88 & & 0.89 & 0.91 & 1 & & & & & & & & \\
\hline MCBI1 & 0.89 & & 0.89 & 0.90 & 0.89 & 1 & & & & & & & \\
\hline MCBI2 & 0.85 & & 0.85 & 0.87 & 0.88 & 0.87 & 1 & & & & & & \\
\hline MCBI3 & 0.87 & & 0.88 & 0.90 & 0.90 & 0.89 & 0.87 & 1 & & & & & \\
\hline MCBI4 & 0.85 & & 0.85 & 0.88 & 0.88 & 0.87 & 0.87 & 0.90 & 1 & & & & \\
\hline MCBI5 & 0.86 & & 0.85 & 0.88 & 0.87 & 0.87 & 0.84 & 0.88 & 0.86 & 1 & & & \\
\hline MCK1 & 0.89 & & 0.88 & 0.91 & 0.90 & 0.91 & 0.86 & 0.90 & 0.88 & 0.90 & 1 & & \\
\hline MCK2 & 0.87 & & 0.86 & 0.88 & 0.87 & 0.87 & 0.85 & 0.87 & 0.86 & 0.86 & 0.89 & 1 & \\
\hline MCP1 & 0.88 & & 0.87 & 0.90 & 0.88 & 0.89 & 0.86 & 0.89 & 0.88 & 0.88 & 0.90 & 0.89 & 1 \\
\hline
\end{tabular}

values suggests that the Burma dek germplasm collection major contributory factors to the narrow range of similarity represents a genetically identical population. One of the co-efficient observed in Burma dek may be on account of 
its evolutionary status as apredominantly self-pollinated species. Johar et al. (2015) has reported the predominantly self pollinated behaviour while studying the phenological and reproductive behaviour of Melia composita. Similar finding have already been reported by Dhillon et al. (2012) in Jatropha curcas.

The cluster tree analysis (dendrogram) (Figure 1) in present investigation showed the broad division of 24 genotypes into 2 major clusters between similarity coefficients of 0.84 to 0.92 . Cluster I comprised of two out grouped accessions

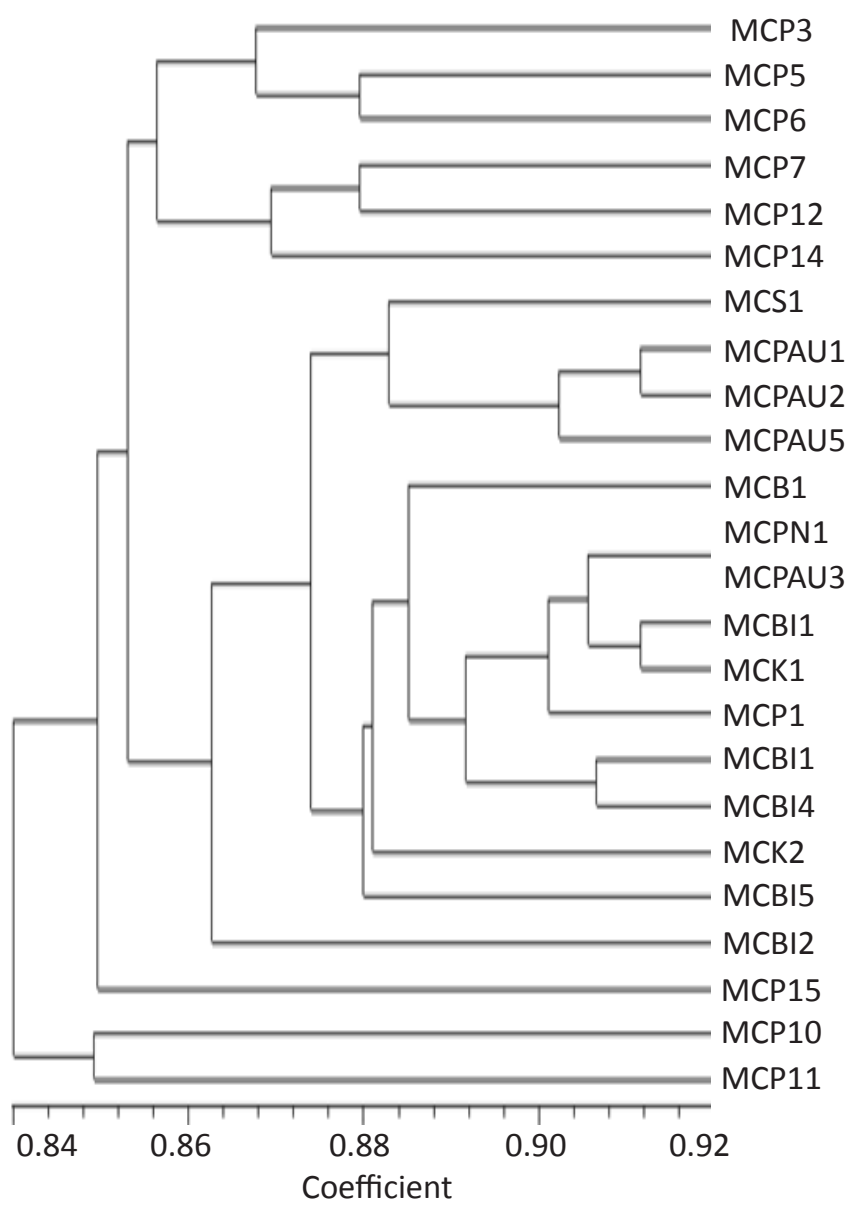

Figure 1: Dendrogram showing genetic relationship among 24 genotypesof Melia composita based on 38 RAPD primers

(MCP10 and MCP11) and cluster II consisted of the rest of 22 accessions/genotypes. Clustering together of accessions from different regions indicates lack of gene flow between adjacent populations in each region. This assumption has seen further supported by Farooqui et al. (1998). Relationship among accession/genotypes was also resolved by Principal Component Analysis (PCA). The overall grouping pattern of PCA corresponded well with the clustering pattern of dendrogram. Accession MCP10 and MCP11 were out grouped in the dendrogram, were occupying the periphery position in 2-D and 3-D PCA (Figure 2 and Figure 3). Rest of the genotypes were grouped into one main group. Hence, PCA showed a further

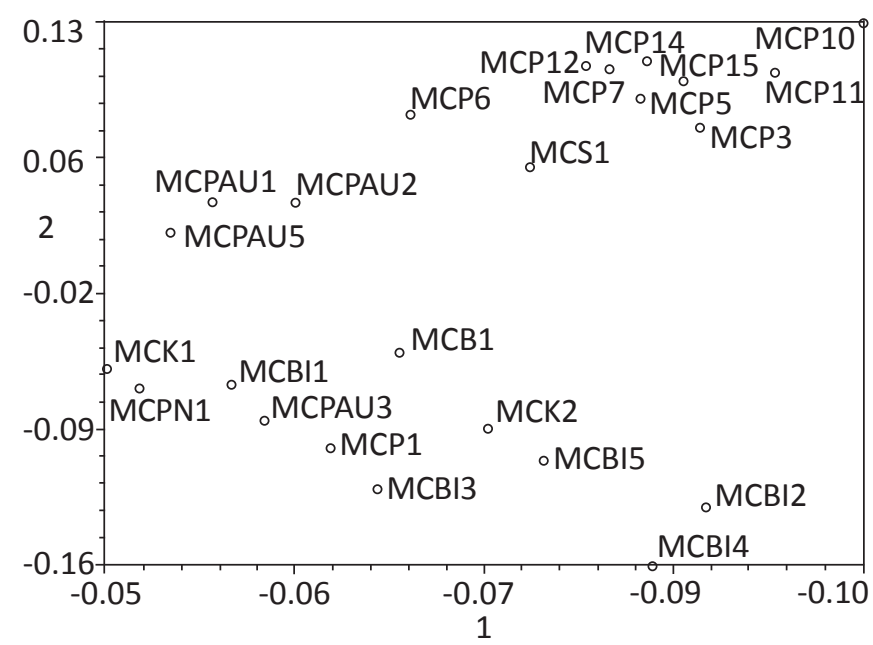

Figure 2: Two dimensional PCA scaling of 24 genotypes of Melia composita using 38 RAPD primers

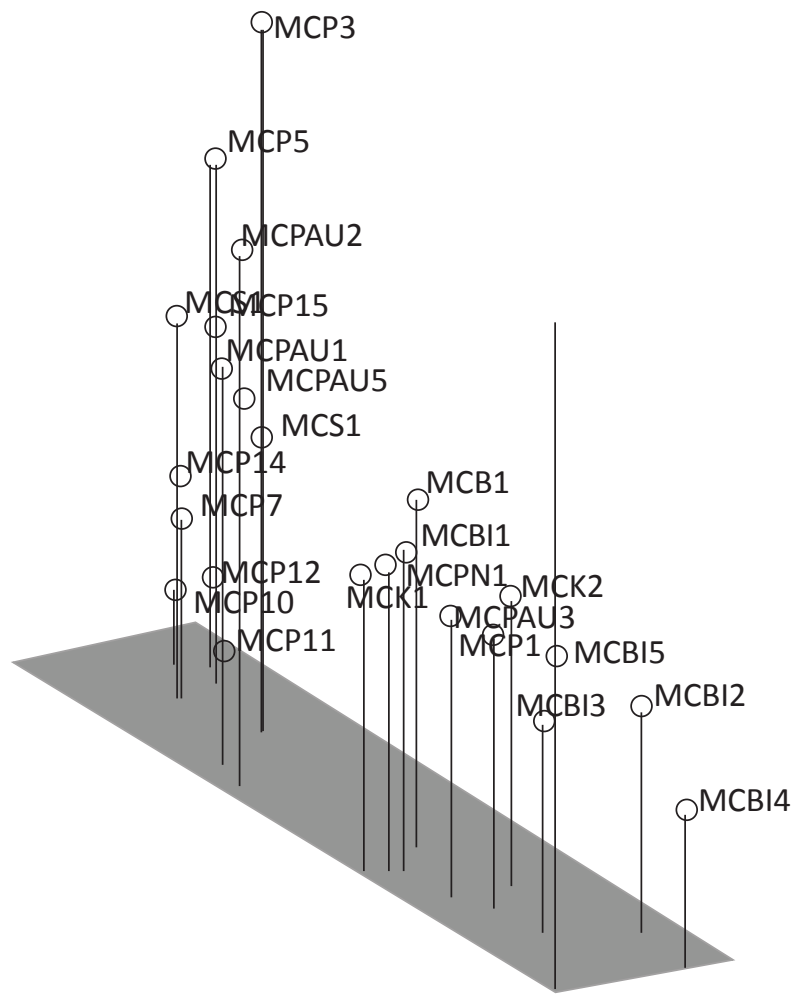

Figure 3: Three dimensional PCA scaling of 24 genotypes of Melia composita using 38 RAPD primers

confirmation of genetic similarities delineated employing UPGMA. Cluster analysis of genotypes on Melia composita employing UPGMA as well as principal component analysis led to the segregation of the accessions into the distinct groups, which reflected their geographical distribution. Variation in genetic diversity within species is usually related with geographical range, mode of reproduction, mating system, seed dispersal and fecundity (Loveless, 1992). The level of genetic variation detected within the Burma dek accessions with RAPD analysis suggested that it is an efficient marker 
technology for delineating genetic relationships among genotypes and estimating genetic diversity, thereby enabling the formulation of appropriate strategies for management, conservation and tree improvement programme.

\section{Conclusion}

PCR based fingerprinting technique, RAPD; is informative for estimating the extent of genetic diversity as well as to determine the pattern of genetic relationships between different candidate plus trees (CPTs) of Melia composita with polymorphism levels sufficient to establish informative fingerprints with relatively fewer primer sets. The genetic similarity among different Candidate plus trees is high as indicated by RAPD analysis which shows a narrow genetic base. Hence the study provides a basis for tree breeders to make informed choices on selection of parental material based on genetic diversity to help overcome some of the problems usually associated with a tree crop improvement program.

\section{References}

Awang, K., Lim, C.S., Mohmad, K., Mosita, H., Hirasawa, Y., Takiya, K., Thoison, O., Hadi, A.H.A., Ceramicine, A., Wolsogyne, A., 2007. Erythrocarpines A-E, new cytotoxic limonoids from Chisocheton erythrocarpus. Bioorganic and Medicinal Chemistry 15(17), 5997-6002.

Chinnaraj, S., Malimuthu, C., Subrahmanyam, S.V., 2011. Development of micropropagation and minicutting protocol for fast growing Melia, Dalbergia and Eucalyptusclones for pulpwood and bioenergy plantations. In: IUFRO Tree Biotechnology Conference Proceedings, 332-334.

Dhillon, R.S., Jattan, M., Singh, C., Rizvi, R.H., Rani, T., 2012. Assessment of genetic diversity in Jatropha curcas (L.) germplasm from India using RAPD markers. Indian Forester 138(6), 491-497.

Endo, T., Kita, M., Shimada, T., Moriguchi, T., Hidaka, T., Matsumoto, R., Hasegawa, S., Omura, M., 2002. Modification of limonoid metabolism is suspension cell culture of Citrus. Plant Biotechnology 19, 397-403.

Farooqui, N., Ranade, S.A., Sane, P.V., 1998. RAPD profile variation amongst provenances of Neem. Biochemistry and Molecular Biology International 45(5), 931-939.

Govindachari, T.R., 1992. Chemical and biological investigation on Azadirachta indica (neem tree). Current Science 63, 117-122.

Johar Vishal, Dhillon, R.S., Bangarwa, K.S., Ajit and Handa, A.K.Phenological behaviour and reproductive biology of Melia composita. Indian Journal of Agroforestry, 17(1) (2015) 62-67.

Karp, A., Issac, P.G., Ingram, D.S., 1998. Molecular tools for screening biodiversity (Plants and Animals). Chapman \& Hall, London.
Kiritkar, K.R., Basu, B.D., 1999. Indian medicinal plants. International Book Distributors, Dehradun, 545-546.

Kokwaro, J.O., 1976. Medicinal plants of East Africa, East African literature Bureau, Nairobi, 223: In: Proceedings of thr Kenyan Seminar on Agroforestry. IARAF, Nairobi, 377-386.

Koul, O., Singh, G., Singh, R., Singh, J., Daniewski, W.M., Berlozenki, S., 2004. Bioefficacy and mode of action of some limonoids of salannin group from Azadirachta indica A. JUSS and their role in a multi component system against lepidoptran larvae. Journal of Biosciences 29(4), 409-416.

Loveless, M.D., 1992. Isozyme variation in tropical trees. New Forest 6, 67-94.

Mandang, Y.I., Artistin, S., 2003. Wood anatomy and fiber quality of utap-utap (Aromadendron elegans BI.) and seven other lesser known wood species. BulletinPenelitian- Hasil- Hutan 21(2), 111-127.

Murray, M.G., Thompson, W.F., 1980. Rapid isolation of high molecular weight plant DNA. Nucleic Acids Research 8, 4321-4325.

Murugesan, S., Senthikumar, N., Rajesh Kannan, C., Vijayalakshmi, K.B., 2013. Phytochemical characterization of Melia dubia for their biological properties. Der Chemica Sinica 4(1), 36-40.

Rohlf, F.L., 1990. NTSYS-PC Numerical taxonomy and multivariate analysis system. Version 1.60. applied Biostatistics, New York.

Saghai-Maroof, M.A., Soliman, K.M., Jorgensen, R.A., Alld, R.W., 1984. Ribosomal DNA spacerlength polymorphism in barley: Mendelian inheritance, chromosomal location and population dynamics, Proc. National Academy Science, U.S.A. 81, 8014-8019.

Simmonds, N.W., 1962. Variability, its use and conservation. Biological Reviews 37, 422-465.

Soltis, E.D., Soltis, P.S., 2012. Isozymes in plant biology. Chapman \& Hall, London, 1990.

Swaminathan, C., Rao, V., Shashikala, S., Preliminary evaluation of variations in anatomical properties of Melia dubia CAV. Wood. International Research Journal of Biological Sciences 1(4), 1-6.

Tatineni, V., Cantrell, R.G., David, D.D., 1996. Genetic diversity in elite cotton germplasm determined by morphological characteristics and RAPDs. Crop Science 36, 186-192.

Wang, B.Y., Sun, J.X., Liu, K.Q., Yang, X.Q., 2003. The study on the stability of RAPD-PCR. Journal of Yunnan University 25, 386-372.

Wang, W.Y., Pai, R.C., Lai, C.C., Lin, T.P., 1994. Molecular evidence for the hybrid origin of Paulownia taiwaniana based on RAPD markers and RFLP of chloroplast DNA. Theoretical Applied Genetics 89, 271-275.

Xu, Y., Shimoro, X., Hofstra, H., 1994. Plant DNA isolation protocol. Nucleic Acids Reserch 22, 2399-2403. 